\title{
HADIS PREDIKTIF DALAM KITAB AL-BUKHARI
}

\author{
Abdul Fatah Idris \\ Dosen Fakultas Syari'ah IAIN Walisongo Semarang \\ e-mail: abdulfatah@walisongo.ac.id
}

\begin{abstract}
This study of predictive hadith in the book al-Bukhārī give results; first, that all the predictive sanad are single transmission (ahad). The predictive hadith through single transmission cannot be credible when it occurs tadlis, suspicion and ghaira ittișāl (not continued). Second, the predictive of matan hadith is a tradition which should not be leaned by the Prophet. However, it is learned by the companions of the Prophet. Is name is mauquf hadith, If is leaned by tabi'in or itba' tabi'in generation, it is called a maqtu'. The state of validity in matan predictive Hadith, depends on the state of the validity in sanad of Hadith. The state of avoiding disability ('illat) of hadith sanad, is very decisive against the state on the validity of hadith matan, However, the state of validity on the hadith sanad is not necessarily a validity on the hadith matan. Therefore, some of predictive of hadith in book of Sahih al-Bukhari found disability in sanad of Hadith and in matan of hadith. In short, the direct or indirect predictive hadith in the the book of al-Bukhāri has disability ('illat), because it contains the contrary to the Qur'an, a political nature, and theological and dogmatic feud.
\end{abstract}

Abstrak: Studi terhadap hadis prediktif dalam kitab al-Bukhārī ini memberi tiga hasil; pertama bahwa semua sanad predikif itu merupakan transmisi tunggal (ahad). Hadis prediktif melalu transmisi tunggal tidak kredibel ketika terjadi tadlis, kecurigaan, dan ghaira ittișāl (tidak bersambung). Kedua, bahwa matan hadis prediksi sebuah hadis yang seharusnya tidak di-marfu'-kan kepada Nabi, tetapi merupakan hadis mauquf yang disandarkan kepada sahabat, dan maqtu' yang disandarkan kepada tābi'în atau itba'tābi'în. keadaan kredibilitas matan hadis prediksi, tergantung pada keadaan kriteria sanad hadis. Kriteria terhindar dari 'illat (cacat) pada sanad hadis adalah sangat menentukan terhadap keadaan kredibilitas matan hadis, tetapi keadaan kredibilitas pada sanad hadis tidak serta merta menjadi kredibilitas pada matan hadis. Sebagian matan hadis prediktif dalam kitab Șahịh al-Bukhārī mempunyai 'illat dalam sanad hadis dan 'illat dalam matan hadis. Matan hadis-hadis prediksi yang diteliti baik secara langsung maupun tidak langsung adalah mengandung illat karena bertentangan dengan al-Quran, mengandung hal-hal yang bersifat politis, serta mengandung pertentangan teologis dan dogmatis.

Keywords: Hadis, Sunnah, Kriteria, Sanad, Matan, dan Prediktif

\section{A. Pendahuluan}

Pemikiran di bidang hadis pasca abad III $H$, tepatnya setelah terkodifikasikannya kutub al-sittah, hanya terbatas pada pensyarahan, ringkasan, atau penyeleksian hadis-hadis tematik dalam sebuah kitab. Praktis kegiatan yang mengarah pada krtisisme sanad maupun matan tidak banyak dilakukan. Karenanya, ketika terjadi pemikiran kritis terhadap hadis-hadis yang sudah terkodifikasikan di 
dalam kitab-kitab hadis, khususnya pada Șaḥịh al-Bukhārī umat Islam mengalami kekagetan intelektual.

Gugatan terhadap hadis yang selama ini sudah dinilai sahih menimbulkan penolakan, bahkan pelakunya dituduh sebagai pro-Barat yang mempunyai agenda tersembunyi (hidden agenda) dan dituduh mengingkari hadis (inkar al-sunnah). Amin Abdullah menengarai, mudahnya vonis inkar al-Sunnah kepada sosok yang mencoba melakukan pengembangan pemikiran terhadap hadis, mengakibatkan para ulama lebih banyak mengendalikan diri dan bersikap segan untuk menelaah ulang pemikiran terhadap hadis. ${ }^{1}$

Pada kenyataannya, terdapat sebagian hadis-hadis dalam kitab sahih alBukhari, tidak selalu mudah untuk diaplikasikan di masa sekarang. Sebab sebagian informasi dalam hadis-hadis itu terkadang sudah tidak sesuai lagi dengan kemajuan ilmu pengetahuan yang berkembang pada saat ini; Belum lagi informasi yang termuat dalam hadis masih dipertanyakan autentisitas dari pembawa berita serta materi berita yang disampaikannya.

Salah satu matan hadis yang dipandang penting untuk dilakukan penelitian adalah hadis-hadis prediktif, yang menurut Fazlur Rahman, sebagian hadis prediktif adalah matan hadis yang bukan bersumber dari Nabi, tetapi hadis-hadis yang bersumber dari para sahabat dan penerusnya. Hadis prediktif kemungkinan banyak terdapat diberbagai koleksi hadis, dan salah satunya adalah terdapat di dalam Sậị al-Bukhārī. ${ }^{2}$ Salah satu contoh matan hadis prediktif bersumber dari Șaḥịh alBukhārī:

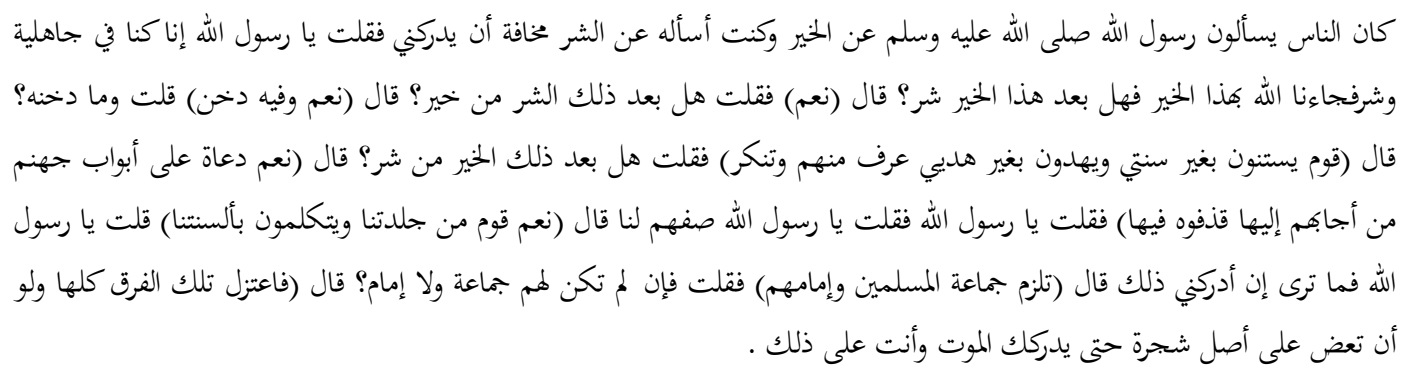

“Orang-orang biasanya bertanya kepada Nabi mengenai kebajikan tetapi aku bertanya mengenai kejahatan karena aku takut tergelincir ke dalam kejahatan. Aku bertanya 'Ya Rasulullah! Di masa lampau kami berada di dalam kebodohan serta kejahatan dan setelah itu Allah membawakan kebajikan ini (melalui 
engkau). Akan adakah kejahatan sesudah kebajikan in? Nabi menjawab: 'Ya! 'Dan apakah kebajikan ini akan kembali lagi sesudah kejahatan itu?' tanyaku. Nabi menjawab 'Ya, namun di dalamnya terdapat penyelewengan'.'Apakah penyelewengan-penyelewengan itu?' tanyaku, Nabi menjawab: ' Ada orangorang yang mengikuti hal-hal yang bukan sunnahku dan memberi bimbingan ke arah yang berlainan dari yang kuberikan. Ada perbuatan-perbuatan yang baik dan ada pula perbuatan-perbuatan yang jahat'. Aku bertanya: 'Apakah setelah kebajikan (yang bercampur dengan penyelewengan-penyelewengan) ini timbul kejahatan?'Ia menjawab: 'Ya, orang-orang yang menyeru dan berdiri di pintu neraka. Barang siapa mendengar mereka pasti akan dilemparkan mereka ke dalam neraka'.Jelaskanlah kepada kami siapakah mereka itu ya Rasulullah!' aku bermohon. Nabi menjawab: Mereka adalah sebangsa dengan kita dan mempergunakan bahasa yang sama. Apakah yang engkau perintahkan kepadaku apabila aku berada di dalam situasi yang seperti itu?, aku bertanya. Nabi menjawab: Berpeganglah kepada pihak mayoritas kaum Muslimin dan pemimpin politik mereka? aku terus bertanya. Nabi menjawab: Jika demikian tinggalkanlah mereka semua sekalipun engkau harus bergantung kepada akar sebuah pohon hingga ajalmu."

Menurut Rahman bahwa hadis ini mengandung sifat prediksi atau ramalan, baik yang bersifat langsung maupun tidak langsung, sehingga tidak dapat diterima sebagai hadis yang benar-benar bersumber dari Nabi. Karena hadis secara kontekstual harus bisa ditafsirkan secara situasional dan diadaptasikan ke dalam situasi dewasa ini (historis-sosiologis). ${ }^{3}$ Dari pandangan-pandangan tersebut di atas, muncul gagasan untuk dilakukan penelitian terkait dengan takhrij hadis-hadis prediktif dalam kitab Saḥịh al-Bukhārī. Di sīni timbul permasalahan: bagaimana kualitas sanad dan matan hadis-hadis prediktif dalam Șahīh al-Bukhārī? Apa yang menjadi kriteria hadis-hadis prediksi sebagai matan hadis yang tidak sahih?

\section{B. Kriteria Kesahihan Hadis}

Untuk menentukan seberapa banyak ketentuan kriteria kesahihan hadis yang betul-betul dikatakan bersumber dari Nabi, para ulama klasik maupun ulama kontemporer secara tegas tidak lepas dari dua hal pokok yang harus ada di dalam 
menentukan sebuah hadis yang sahih yaitu fokus pada persoalan matan dan fokus pada sanad hadis. Sistem isnād sebagai cara penelusuran hadis yang melalui orangorang yang terpercaya diyakini sebagai jalan yang meyakinkan dalam rangka penerimaan hadis yang diterima sebagai sebuah hadis yang sahih, daripada mendahulukan penelusuran hadis melalui sistem matan. Sebagaimana pernyataan Abd Allāh al-Mubārak bahwa isnād merupakan bagian dari agama:

$$
\text { عبدالله بن المبارك يقول الإسناد من الدين ولولا الإسناد لقال من شاء ما شاء ( رواه مسلم : / / I ) }
$$

Ibnu al-Mubarak mengatakan bahwa isnad itu termasuk bagian dari agama, dan seandainya tidak ada isnad, niscaya setiap orang akan mudah mengatakan sesuatu yang dikehendakinya (HR. Muslim).

Sanad hadis akan menjadi urgen apabila dilakukan penelitian terhadap rawirawi hadis yang membentuk sanad itu sendiri. Karena dengan meneliti sanad dapat diketahui apakah silsilah rawi-rawi itu bersambung sampai kepada Nabi saw. atau tidak. Dapat diketahui pula, apakah masing-masīng rawi dapat dipertanggungjawabkan pemberitaannya atau tidak. Dan akhirnya dapat diketahui apakah hadis yang diriwayatkan itu dapat dinilai sebagai hadis sahih (otentik) atau tidak. Kriteria kesahihan sanad saja belum cukup untuk dinilai sebagai hadis yang betul-betul bersumber dari Nabi saw., tetapi masih diperlukan adanya ketentuan lain, yakni mengenai materi (matan) hadis itu sendiri. Hal ini didasarkan kepada kenyataan bahwa kadang-kadang dijumpai hadis yang ber-sanad sahih, namun matan hadisnya dinilai lemah ( $(\underline{a} \bar{i} i f)$ dan atau sebaliknya.

Para ahli hadis masa awal sampai abad III $\mathrm{H}$ tidak secara eksplisit mendefinisikan hadis-hadis yang dapat dianggap sahih. Mereka hanya menetapkan kriteria-kriteria informasi yang diperoleh, misalnya, al-Rāzī dalam karyanya "al-Jarḥ wa at-ta'dil" mensyaratkan: (1) Periwayatan hadis tidak dapat diterima, kecuali kalau diriwayatkan oleh orang-orang yang iqqah; (2) Riwayat orang-orang yang sering berdusta, mengikuti hawa nafsunya, dan tidak memahami secara benar apa yang diriwayatkan adalah tertolak; (3) Kita harus memperhatikan tingkah laku persoalan dan ibadah orang-orang yang meriwayatkan hadis; (4) Apabila mereka terbiasa berkelakuan tidak terpuji dan tidak melakukan salat secara teratur, maka riwayatnya harus ditolak; (5) Riwayat orang-oarang yang tidak dikenal piawai dalam 
ilmu-ilmu hadis tidak dapat diterima; dan (6) Riwayat orang-orang yang kesaksiannya ditolak, maka riwayatnya pun tidak diterima. ${ }^{4}$

Kriteria ini belum mencakup keseluruhan syarat kesahihan sanad, apalagi kriteria mengenai kesahihan matan. Hal ini dapat digambarkan beberapa pandangan ulama tradisionalis dan kontemporer terhadap sikap ketegasan mereka dalam menjelaskan kriteria dalam menentukan sebagai kriteria autentisitas kesahihan hadis, antara lain:

Pertama, al-Syāfi'ī menjelaskan kualifikasi yang harus dimiliki oleh seorang perawi hadis sebagai berikut: ${ }^{5}$

a. أن يكون مَنْ حدََُّ به ثِفَعَة في دينه harus terpercaya dalam agamanya

b. معروفاً بالصِّدق في حديثه = harus dikenal selalu benar dalam penyampaian berita

c. عالماً بما يُجيل مَعَانِيَ الحديث مِنَ اللفظ harus memahami isi berita, mengetahui secara benar bagaimana perubahan lafal akan mempengaruhi gagasan yang disampaikan

d. أن يكون من يُوَّدِّي الحديث بحروفه كما سَمَعَ لا يحدث به على المعنى لأنه إذا حلََّث على المعنى وهوغير harus menyampaikan laporan secara verbal (lafz $\} \bar{l})$ sesuai yang ia dengar, dan tidak menyampaikan dengan kalimatnya sendiri .

e. حافظاً إن حدَّث به مِنْ حِفْظِه حافظاً لكتابه إن حدَّث مِنْ كتابه harus memiliki daya ingat yang tinggi apabila ia menyampaikan atau menerimanya lewat hafalan dan harus menjaga catatan apabila ia menyampaikan/ menerimanya dari catatan atau kitabnya.

f. Riwayatnya harus sesuai dengan riwayat mereka yang dikenal memiliki tingkat akurasi hafalan yang tinggi, apabila mereka juga turut meriwayatkan hadis yang sama, dan laporannya tidak berbeda dari laporan orang-orang siqqah.

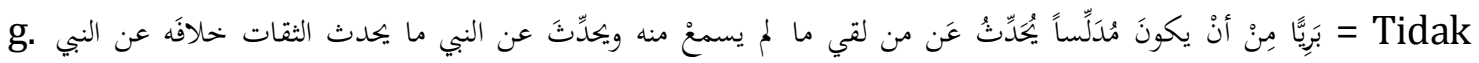
membuat laporan atau riwayat atas nama mereka yang pernah ia temui, tetapi pernah belajar darinya, syarat-syarat ini harus dipenuhi oleh seluruh perawi mulai dari generasi sampai terkhir.

Kedua, Ibn Hajar (w. 732 H.) menyatakan, bahwa Șahīh al-Bukhārī karya Imām Bukhārī (w. 256 H) dan Șaḥih Muslim karya Imām Muslim (w. 261 H) adalah dua kitab yang paling otentik. Namun demikian, di dalam kedua kitab tersebut, terutama 
Sahịịh al-Bukhārī sendiri tidak pernah menjelaskan secara detail kriteria yang mereka terapkan dalam menguji otentisitas hadis. Hanya saja kriteria yang dinyatakan Șaḥịh al-Bukhārī itu oleh para ulama yang datang kemudian mencoba menghimpun syaratsyarat hadis sahih yang ditulis Imām Bukhārī dan Muslim. Sebagaimana dinyatakan Ibn Șālah berikut ini:

$$
\begin{aligned}
& \text { شرط مسلم رممه الله تعالى في صحيحه أن يكون الحديث متصل الاسناد بنقل الثقة عن الثقة من أوله إلى منتهاه سالما من الشذوذ والعلة } \\
& \text { قال وهذا حد الصحيح فكل حديث اجتمعت فيه هذه الشروط فهو صحيح بلا خلاف بين أهل الحديث (شرح النووي على مسلم: } \\
& \text { جزء 1 - صفحة 10). }
\end{aligned}
$$

Imām Muslim dalam kitab sahihnya, bahwa syarat-syarat hadis sahih adalah hadis yang bersambung sanadnya, diriwayatkan oleh perawi yang siqah, baik dari awal sampai akhir, terhindar dari syużūd (kejanggalan) dan dari 'illah (cacat). Jadi setiap hadis yang terpenuhi syarat-syarat tersebut, dikatakan sebagai hadis sahih, yang tanpa diperselisihkan di antara ahli hadis.

Muhibbin (L.1960 M) telah memberikan pertimbangan teori kriteria alternatif dalam tulisan disertasi "Telaah Ulang atas Kriteria Kesahihan Hadis-Hadis al-Jāmi" alȘạḥ̄ḥ", yaitu: 1) perawi yang meriwayatkan hadis secara obyektif harus benar-benar bersifat adil. Sedangkan batasan untuk dapat disebut sebagai orang yang adil, harus memenuhi syarat yakni: Islam, mukallaf, melaksanakan syariat Islam, dan memelihara muru'ah; (2) perawi yang meriwayatkan hadis secara obyektif harus benar-benar bersifat dābit; (3) sanad hadis secara obyektif harus bersambung; dan (4) terhindar dari syāż (kejanggalan).

Teori kriteria alternatif yang sangat dipentingkan, menurut Muhibbin, adalah dalam memberikan pemaknaan arti syāż yang secara subtansi harus dibedakan dengan para ulama hadis pada lazimnya. Yaitu, syāż dimaksudkan tidak mengandung kejanggalan-kejanggalan yang berupa: (1) bertentangan dengan naș qațī, yakni alQuran dan Sunnah Mutawātirah; (2) bertentangan dengan dalil-dalil yang meyakinkan dan tidak dapat dita'wilkan seperti kesimpulan-kesimpulan dalam berbagai bidang ilmu pengetahuan, baik medis, astronomi, maupun yang lain; (3) bertentangan dengan sìrah dan perbuatan Nabi sendiri; (4) bertentangan dengan fakta sejarah yang terjadi pada zaman Nabi Muhammad saw, ataupun pada zaman sebelum atau sesudahnya; (5) bertentangan dengan kesimpulan-kesimpulan yang 
dihasilkan oleh akal sehat, misalnya materi hadis tersebut harus tidak cenderung memihak pada salah satu mażhab yang ada, tidak menyerupai gaya bahasa fikih yang muncul jauh setelah masa Nabi saw dan; (6) mengandung istilah-istilah yang belum dikenal pada zaman Nabi, dan lainnya. ${ }^{6}$

Keempat, Fazlur Rahman (1919-1988). Aspek matan hadis yang tidak kalah penting dan untuk dipertimbangkan adalah gagasan Rahman yang mencakup matan hadis yang memiliki sejumlah 'illat (kecacatan) dan syużūż (kejanggalan), antara lain: (1) matan hadis tidak bersifat spesifik (khas), (2) matan hadis bukan pengecualian, (3) matan hadis tidak bersifat prediksi (ramalan) ataupun mengandung prediksi, (4) matan hadis prediksi tidak mengandung sifat politis dan hukum, (5) matan hadis bersifat situasional atau bersifat historis, (6) matan hadis relevan dengan al-Qur'an, dan (7) matan hadis dapat diadaptasikan (sunnah ideal) atau tidak bersifat kaku. ${ }^{7}$

Dari deskripsi di atas, aspek penting untuk memberikan penilaian kesahihan sebuah hadis yang betul-betul bersumber dari Nabi saw, adalah menyangkut kriteria aspek sanad dan aspek matan. Demikian pula untuk menentukan sejauhmana hadishadis prediktif dikatakan sebagai hadis yang tidak bersumber dari Nabi, maka perlu diukur dengan kriteria yang secara baku yang diungkap oleh para ulama klasik maupun kontemporer.

\section{Hadis dan Hadis Prediktif}

\section{C.1. Konsep Hadis dan Sunnah}

كون الثيء بعد أن لم يكن : (adanya sesuatu setelah tidak adanya). ${ }^{8}$ Sedangkan Ibn Manzūr memberi makna 'ḥadīs' dengan jadīd (yang baru), yang merupakan lawan qadìm (yang lama) atau dikatakan, kalam (pembicaraan). ${ }^{9}$ Selain itu, Subhki juga memaknai 'ḥadīs' dengan khabar (berita). ${ }^{10}$

Muḥādisīn mengkonsepsikan makna hadis dan sunnah secara umum adalah segala ucapan, perbuatan, taqrīr dan sifat-sifat Nabi Muhammad saw. Sedangkan Fazlur Rahman mengartikan konsep hadīs adalah ceritera, penuturan atau laporan, atau sebuah narasi singkat tentang apa yang dikatakan, dilakukan, disetujuai atau tidak disetujui oleh Nabi, dan juga informasi yang sama mengenai para sahabat. ${ }^{11}$ Atau Hadis merupakan refleksi verbal dari Sunnah yang hidup. Karena hadīs ini 
diawali dari adanya sebuah ijtihad yang dilakukan oleh generasi pertama kaum Muslimin. ${ }^{12}$

Dalam kitab Șaḥịh al-Bukhārī makna hadis dan sunnah belum dikonsepsikan oleh Imām al-Bukhārī, seperti halnya konsepsi hadis dan sunnah oleh ulama hadis lainnya, baik secara etimologi maupun terminologi. Namun setelah banyak diketahui ungkapan kata-kata hadis dan sunnah yang ada di dalamnya, maka ulama hadis mendefinisikannya seperti tampak di bawah ini:

a Makna hadis didefinisikan sebuah kejadian terdapat di dalam kitab Șaḥịh alBukhārī (1987: IX, 54) yang dinyatakan:

$$
\text { عن النبي صلى الله عليه وسلم قال :........ومن استمع إلى حديث قوم وهم له كارهون ،(رواه البخاري : } 9 \text { / ؛ 0) }
$$

Dari Nabi saw bersabda:..... Dan orang-orang yang mendengar hadis (cerita) suatu kaum sedangkan mereka benci terhadapnya. (H.R. al-Bukhari)

b Kata Sunnah yang diungkap dalam kitab Ṣạ̣ịh al-Bukhārī yang menunjukan maknanya, misalnya:

$$
\begin{aligned}
& \text { قال : أنتم الذين قلتم كذا وكذا أما والله إني لأخشاكم لله وأتقاكم له لكني أصوم وأفطر وأصلي وأرقد وأتزوج النساء فمن رغب عن سنتي } \\
& \text { فليس مني. (رواه البخاري V / T) }
\end{aligned}
$$

Rasulullah mengatakan: Apakah kamu sekalian yang mengatakan begini....begini...... Demi Allah sesungguhnya aku adalah orang yang lebih takut pada Allah daripada kamu, tetapi sungguh aku berpuasa dan berbuka, aku salat dan juga tidur, dan aku juga mengawini wanita, maka barang siapa yang benci pada sunah-ku adalah bukan termasuk golonganku (H. R. al-Bukhari).

\section{C.2. Makna Hadis Prediksi}

Prediksi merupakan kata Indonesia serapan dari bahasa Inggris 'predict' yang berarti "pendapat, pernyataan, ceramah tentang pelajar."13 Dalam Kamus InggrisArab, kata 'predict' disamaartikan dengan أنباً (memberitakan), تكهن (meramal), رجم بالغيب (berbicara sesutu yang belum diketahui). ${ }^{14}$ Kata "ramal" yang mendapat awalan (me-) dapat diartikan: (a) melihat nasib orang dengan membuka ramal; (b) menduga; menelaah; (c) meramalkan yakni melihat (menduga) keadaan (hal) yang bakal terjadi. Ramalan adalah hasil yang diperoleh dari meramal. ${ }^{15}$ 
Hadis prediksi dalam kajian ini, didefinisikan oleh Fazlur Rahman sebagai hadis yang tidak bersumber dari Nabi Muhammad saw, tetapi merupakan hadis-hadis yang diformulasikan dan seolah-olah bersumber dari Nabi. Penolakan Rahman terhdap hadis-hadis prediksi adalah didasarkan bukti-bukti historis yang secara nyata mengandung ramalan baik yang bersifat langsung maupun tidak langsung. ${ }^{16}$

Secara filosofis hadis prediksi bukan bersumber dari Nabi dibuktikan bahwa tugas Muhammad sejak awal diutus Allah SWT, di kota Makkah adalah bertujuan membebaskan praktek-praktek kāhin (peramal) yang menjurus pada penyekutuan terhadap Allah (syirik). Karena itu Muhammad di tegaskan oleh Allah bukan seorang yang gila (tukang sihir atau peramal) sebagaimana dituduhkan oleh orang-orang musyrik. Dalam QS. al-T\{ūr [52]: 29 ditegaskan:

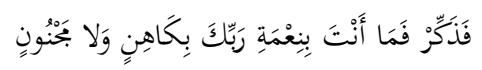

Maka tetaplah memberi peringatan, dan kamu disebabkan nikmat Tuhanmu bukanlah seorang tukang tenung dan bukan pula seorang gila.

Inilah barangkali alasan yang tepat bahwa sebagian hadis-hadis prediksi yang secara langsung atau tidak langsung ataupun secara spesifik yang bertujuan untuk kepentingan golongan politik, dogmatis dan teologis, nyata-nyata bukan bersumber dari Nabi.

\section{C.3. Jenis dan Tanda-Tanda Hadis Prediksi}

Jenis hadis-hadis prediksi (ramalan) ada yang bersifat langsung ada pula tidak langsung. Hadis prediksi yang tidak langsung dapat dilihat dari subtansi atau kandungan matan hadis tersebut, sedangkan hadis prediksi yang langsung dapt dilihat dari tanda-tanda secara umum seperti berikut:

1) Adanya susunan kalimat yang didahului huruf w $(\sin )^{17}$, yang menunjukkan masa yang akan datang, seperti penggunaan kata-kata ستكون atau سيكون (akan terjadi). Contoh:

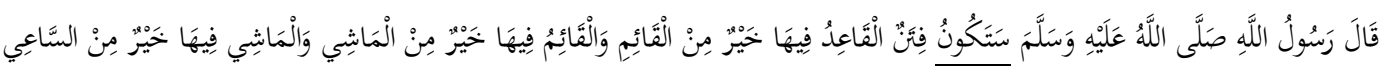

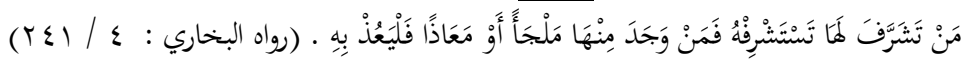

2) Susunan kalimat secara dahir menunjukan pengertian (makna) prediktif dengan menggunakan kata-kata يَكُونُ بَعْدِي... (setelah aku nanti akan....). Contoh hadis Nabi dari imam Muslim: 


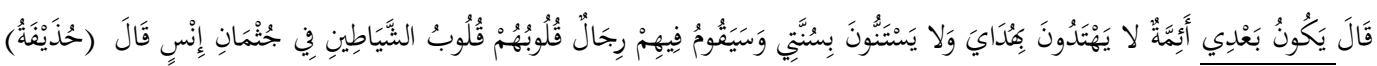

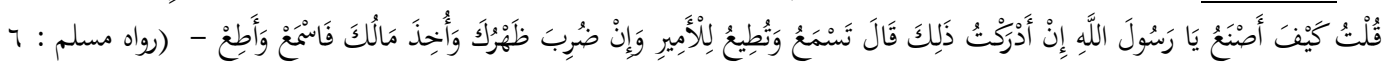

3) Adanya susunan kalimat seperti: سياتي...... سيا. yang menunjukan secara tegas mengandung pengertian (makna) prediktif, karena ditegaskan dengan huruf w (sin), dan disertai kata kerja ياتي (akan datang) yang menunjukan peristiwa yang diramalkan bakal terjadi di masa yang akan datang, dan kadang disebut يأتي saja dengan penambahan kata زمان jebagai kata penguat yang menunjukan betul-betul waktu (zaman) yang akan datang terjadi. Contoh hadis Nabi dari Sahih alBukhari:

$$
\text { قال : 》 سيأتي على أمتي زمان تكتر فيه القراء ، وتقل الفقهاء ويقبض العلم ، ويكثر الهرج 《ي }
$$

4) Hadis prediksi mengandung sifat secara langsung maupun tidak langsung serta bersifat spesifik (Rahman, 1965: 46). Contoh hadis sahih dari imam al-Bukhari:

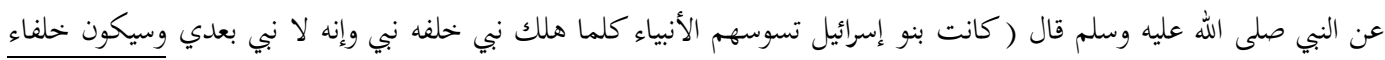

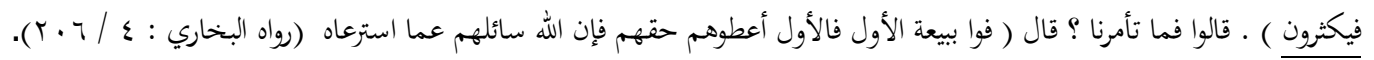

\section{Hadis Prediksi dalam Șaḥịh al-Bukhārī}

Hadis-hadis prediktif di dalam kitab Șaḥịh al-Bukhārī, dapat dilihat dari contohcontoh yang dapat ditelusuri melalui tanda-tanda dan jenisnya. Dan mudah apabila kita ingin mengetahuinya dengan menelusuri melalui tanda-tanda hadis prediktifsecara langsung. Dibanding dengan mengetahui penelusuran hadis-hadis prediktif melalui hadis prediktif yang secara tidak langsung.

\section{D.1. Hadis prediktif secara langsung tentang moral politik:}

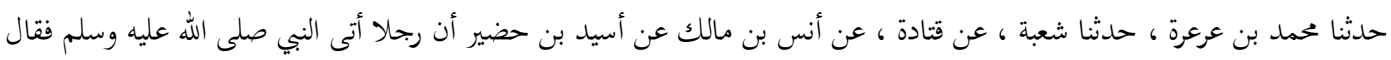

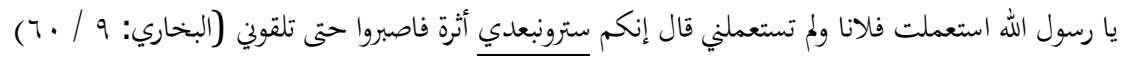

Muhammad bin 'Ar'Arah menceritakan kepada kami, Syu'bah menceritakan kepada kami, dari Qatādah, dari Anas bin Mālik, dari Asyad bin Huḍair, bahwa seorang laki-laki datang kepada Nabi saw, "Wahai Rasulullah engkau telah memberi pekerjaan (jabatan) kepada si Fulan, tetapi engkau tidak memberi jabatan kepadaku." Jawab Nabi: "Sungguh engkau akan melihat setelah aku 
suatu pemilihan (pemimpin), maka bersabarlah sampai engkau bertemu dengan aku" (HR. al-Bukhārī).

Hadis prediktif tentang moral politik ini, setelah dilakukan penelusuran dalam kutub al-sittah, muncul tiga hadis prediktif yang terdapat dalam tiga kitab hadis dan sekaligus sebagai mukhārrij: al-Bukhārī, al-Turmużī, dan Aḥmad bin Hanbāl.

Sanad hadis prediktif ini menunjukkan bahwa dari jalur mukhārrij Imām alBukhārī (194-256 H) dan Imām al-Turmużī (200-279), yang menghubungkan sampai pada Asyad bin Ḥụ̣air (w. 20 H) dikatakan oleh Abū Dāwud bahwa Asyad bin Hụuair hadis-hadisnya adalah tidak bersambung sanadnya (ghaira muttașil) dan Ibn Ḥajar al-Asqalanī mengatakan hadis-hadis dari Asyad bin Ḥuḍair berstatus maqbūl.18 Keterputusan hadis-hadis Asyad bin Hudair ditunjukkan oleh periwayatan yang tidak diketahui identitasnya yang jelas.

Matan hadis prediktif ini jelas-jelas mengandung pertentangan politik yang sengaja dibuat untuk menarik perhatian terhadap golongan mayoritas yang berkuasa, yakni Bani 'Umayah atas golongan ‘Ali bin Abī Ṭālib.

Permusuhan anta golongan adalah bertentangan dengan semangat al-Quran yang mengajak kaum Muslimin untuk menggalang persatuan sebagaimana ditegaskan dalam QS. al-Ḥujurāt [49]: 11.

Melihat penjelasan di atas, ada dua 'illat (cacat) yang dapat menjadikan matan hadis ini lemah (ḍaîff). Pertama, matan hadis ini bertentangan dengan ayat QS. alḤujurāt [49]: 11. Kedua, berbicara tentang al-fitan, yaitu mengandung unsur fanatisme golongan.

\section{D.2. Hadis prediktif secara langsung dalam teologis, dogmatis:}

حدثنا أبو اليمان ، أخبرنا شعيب ، عن الزهري ، أخبربن أبو سلمة بن عبد الرمن أن أبا هريرة قال : قال رسول الله صلى الله عليه وسلم :

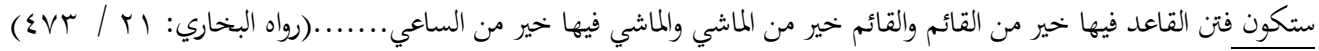

Abū al-Yamān menceritakankepada kami, Syu'aib telah menceritakankepada kami, dari al-Zuhrī, Abū Salamah bin Abd al-Raḥmān memberitakan kepadaku bahwa Abū Hurairah berkata, Rasulullah saw bersabda: "Akan terjadi perang saudara di mana manusia yang duduk di rumah adalah lebih baik daripada yang berdiri, manusia yang berdiri adalah lebih baik daripada yang berjalan, dan 
manusia yang berjalan adalah lebih baik daripada yang berlari, ..(HR. alBukhāri).

Hadis prediktif secara langsung yang mengandung sifat teologis dan dogmatis ini, terdapat pada kitab Șaḥị̣ al-Bukhārī saja. Dalam kitab ini, terdapat dua isnād yang memancar setelah periwayat Abū Salamah peringkat III (Tābi'īn menengah) yang menghubungkan sampai pada Imām al-Bukhārī.

Adapun isnād yang menghubungkan dari jalur mukhārrij Imām al-Bukhārī sampai pada peringkat I, yakni sahabat Abū Hurairah, dinilai positif oleh Ibn Hajar al'Asqalanī dan al-Żahabī , yakni sebagai periwayatan yang siqat (adil). Namun oleh para komentator lain memberikan informasi yang berbeda. Utamanya terhadap sahabat Abū Hurairah (w. $57 \mathrm{H}$ ).

Sebagian ulama menilai Abū Hurairah adalah sebagai salah satu tujuh sahabat yang paling banyak meriwayatkan hadis Nabi. Kemudian oleh ulama lain, seperti Ibn Abd al- Bar (368 - 463 H) ${ }^{19}$ menilai bahwa Abū Hurairah karena namanya kacau (mempunyai banyak nama) sehingga dinilai tidak bisa menjadi pegangan keabsahan hadisnya. Kata al-Nawāwī. Abū Hurairah mempunyai nama lebih dari 30 nama, baik ketika masih di zaman jahiliyah maupun sesudahnya.

Dilihat pada persambungan sanad-nya hanya diriwayatkan oleh sahabat Abū Hurairah dan hanya satu satunya mukhārrij yaitu Imām al-Bukhārī. Menurut pandangan ulama klasik bahwa periwayatan jalur sanad semacam ini, adalah diklasifikasikan sebagai jalur sanad berkualitas ahad (tunggal). Kemudian ditinjau dari segi kualitas para perawi adalah terhambat oleh Farat bin Abī 'Abd al-Raḥmān yang tidak dapat diketahui tahun kelahirannya, sehingga untuk menentukan ittișal (persambungan) sanad diragukan ketersambungannya, namun ternyata dijumpai tambahan sanad dari jalur periwayatan lain, untuk dapat dijadikan muttabi' atau penguat terhadap sanad yang diragukan ittișal-nya, yakni sanad dari perawi al-Zuhrī. Setelah dilakukan pelacakan ternyata pertemuan antara murid dan guru telah terjadi. Oleh karena itu jalur sanad prediktif ini, menurut penulis dapat diklasifikasikan sebagai jalur yang bersambung.

Matan hadis prediksi teologis dan dogmatis ini dimaksudkan untuk memberikan semangat berjuang yang ditujukan kepada orang-orang yang anti terhadap golongan Khawārij. Untuk menindas pemberontakan orang-orang Khawārij 
sebagai pemberontak-pemberontak professional yang tak mungkin diperbaiki. Hadis ini dibuat tujuannya hanyalah untuk mengimbangi aktivisme dan semangat dari orang-orang Khawārij untuk berperan aktif dalam kehidupan berpolitik. Sesungguhnya hadis-hadis yang menyerukan isolasionisme telah berkembang sedemikian jauhnya dengan menyangkal doktrin mayoritas (jama'ah/Sunni). ${ }^{20}$

Jadi hadis ini dapat dilihat dari segi matan-nya adalah sangat erat bernuansa politik dan pertentangan golongan, sehingga matan hadis ini adalah telah memenuhi kriteria tertolaknya kesahihan hadis atau sebagai matan hadis yang mempunyai cacat ('illat).

\section{D.3. Hadis prediktif secara tidak langsung tentang politik:}

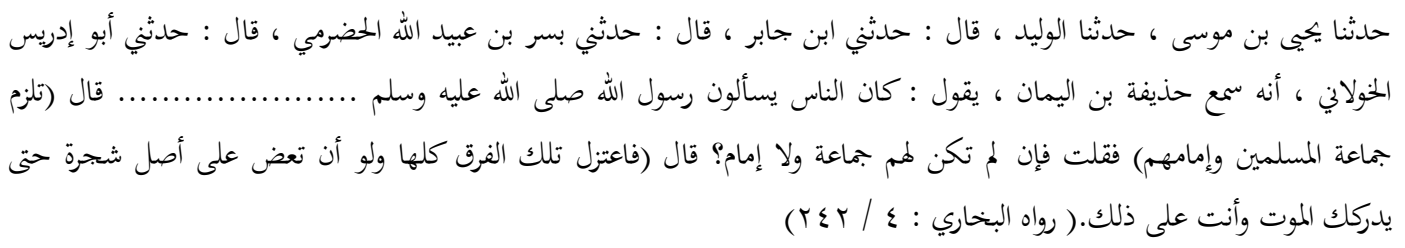

Yahya bin Mūsa menceritakan kepada kami, al-Walīd menceritakan kepada kami, (mengatakan) Ibn Jābir menceritakan kepada saya, (mengatakan) Bisr bin 'Ubaidillāh al-Haḍramī menceritakan kepada saya, (mengatakan) Abū Idrīs alHūlānī menceritakan kepada saya, bahwa ia mendengar Huzaifah al-Yamān mengatakan: “Orang-orang biasanya bertanya kepada Rasulullah saw .....Nabi menjawab: "Berpeganglah kepada pihak mayoritas kaum Muslimin dan pemimpin politik mereka." Aku terus bertanya. Nabi menjawab: “Jika demikian tinggalkanlah mereka semua sekalipun engkau harus bergantung kepada akar sebuah pohon hingga ajalmu" (HR. Șaḥịh al-Bukhārī).

Hadis prediksi ini terdapat dalam tiga kitab dan sekaligus sebagai mukhārrij terakhir, yakni dalam kitab Șaḥịh al-Bukhārī, Șaḥ̄ḥ Muslim dan Sunan Aḥmad bin Hanbāl.

Hużaifah al-Yamānī (Abū 'Abd Allāh al-'Abbāsī) adalah satu-satunya sahabat yang meriwayatkan hadis ini, oleh karena itu hadis prediktif bersifat politik ini merupakan hadis periwayatan tunggal (ahad), dan baru memancar pada peringkat VII yakni al-Walīd bin Muslim al-Damsyiqī. Jaringan isnād hadis prediktif ini dalam klasifikasi klasik adalah sebagai hadis gharīb atau fard. 
Ulama hadis klasik telah memberi penilaian terhadap historitas riwayat terhadap perawi tunggal (ạ̣ad). Menurut Ibn al-Ṣalālah, riwayat perawi tunggal śiqah (hadis gharīb atau fard) diklasifikasi ke dalam tiga kategori: 1) Riwayat perawi siqah yang bertentangan dengan riwayat yang lebih śiqah. Riwayat yang seperti ini harus ditolak dan dianggap syużūż; 2) Riwayat perawi yang bertentangan dengan riwayat perawišiqahlainnya. Riwayat jenis ini diterima; 3) Riwayat yang berada di antara dua jenis kategori di atas. ${ }^{21}$

Adapun matan hadis prediktif yang diriwayatkan oleh Imam al-Bukhari, menyuruh kita untuk berpegang teguh kepada mayoritas kaum Muslimin dan mentaati pemimpin politik (al-jamā'ah) dengan segala resiko. Menurut Fazlur Rahman, hadis ini merupakan hadis ijma' yang berdasarkan kepentingan politik yang memaksa pada masa itu. Seruan bahwa seorang pemimpin yang zalim sekalipun harus ditaati adalah saran yang berdasarkan kepentingan-kepentingan politik; kepentingan-kepentingan ini timbul karena perang saudaa (al-fitan) yang tak kunjung padam. Seruan ini terutama tertuju kepada lawan politiknya yaitu kepada orang-orang Khawārij. ${ }^{22}$

\section{D.4. Hadis prediktif secara tidak langsung bersifat spesifik:}

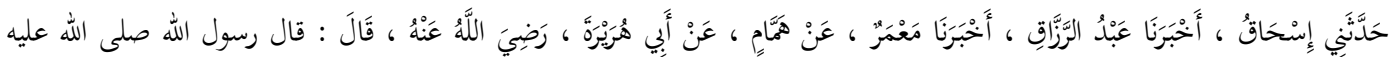

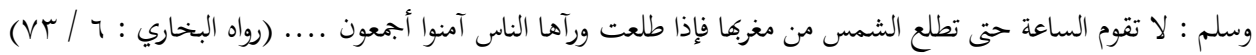

Isḥāq telah menceritakan pada saya, 'Abd al-Razzāq telah memberitaukan kepada kami, Ma'mar telah memberitakan kepada kami, dari Hammām dari Abū Hurairah ra. Mengatakan, Rasulullah bersabda: "Tidak akan terjadi hari kiamat sehingga terbit matahari dari arah barat, maka ketika matahari benar-benar telah terbit, keadaan manusia akan berbondong-bondong beriman (masuk Islam)...(HR. al-Bukhārī).

Setelah dilakukan pelacakan di dalam "kutub al-sittah" menghasilkan informasi bahwa hadis prediktif secara tidak langsung bersifat spesifik, muncul lima mukhārrij yakni: al-Bukhārī, Muslim, Abū Dāwud, Ibn Majāh dan Aḥmad.

Menurut hasil penelitian jalur sanad hadis ini merupakan sanad yang berstatus hadis aḥad (tunggal) karena hanya sahabat Abū Hurairah saja yang meriwayatkan 
hadis tersebut. Kemudian periwayatansanad hadis dari sahabat Abū Hurairah yang melalui jalur sanad sampai mukhārrij Imām Muslim, terdapat kecurangan seorang perawi berbuat tadlīs (waham dan munkar), yaitu bernama al-'Alla' bin 'Abd alRaḥmān (w. 130 H).

Hadis prediktif secara tidak langsung bersifat spesifik ini, sanad-nya tidak kredibel yang melalui mukhārrij Imām Muslim. Demikian pula sanad hadis yang melalui mukh>arrij Imām al-Bukhārī terdapat seorang perawi bernama $\mathrm{Abū}$ alYamān (w. 222 H), telah melakukan tadlīs karena banyak oleh kalangan kritikus (ahli hadis) yang menyatakan Abū al-Yamān tidak pernah meriwayatkan hadis dari periwayat sebelumnya yakni Syu'aib bin Hamzah (w. 162 H), kecuali ia telah meriwayatkan satu hadis tentang "syafa'at", yang tidak ada hubungannya dengan hadis prediktif ini.

Hadis prediktif bersifat spesifik ini, bisa ditolong menjadi hadis sahih apabila didukung oleh hadis lain sebagai muttabi'-nya. Dalam hal ini, para ulama hadis (kritikus) tidak sepakat dalam menyampaikan kata-kata atau penilaian terhadap mereka, seperti ada yang menilai siqqat, ada pula lāba'sa, șudūq, mudallas, maqlublah, dan laisa bijayyid. ${ }^{23}$ Menurut pendapat penulis sanad hadis ini tidak bisa tertolong oleh muttabi' dari mukhārrij Abū Dāwud, Ibn Majāh, dan Aḥmad, karena ada seorang perawi bernama 'Umarah bin al-Qa'qa' berbuat tadlīs, waham dan maqlūb. Dengan demikian hadis prediktif ini sanad-nya lemah (ḍa îf) dan tidak bisa dijadikan hujjah.

Hadis ini sebagai hadis yang musykil, karena mana mungkin bagi seseorang yang mempunyai akal yang sehat dan mendalami ilmu pengetahuan astronomi dan ilmu falak bahwa tidak bisa diterimanya iman seseorang menanti terbitnya matahari dari arah Barat. Adalah sesuatu yang tidak mungkin diterima bagi orang-orang yang berpengetahuan. 24 Lebih lanjut Rāsyid Riḍā (1865-1935 M,) memahami hadis prediksi ini sebagai hadis yang bernuansa politik dan dogmatis, pertentangan tentang permasalahan konsep iman antara golongan Asy'ariyah, Mu'tazilah, dan Sunni. Sehingga pandangan Rāsyid Riḍā ini, telah diadopsi pula oleh pandangan Rahman sebagai hadis spesifik yang bersifat politis dan dogmatis. Dengan demikian, sekalipun Rahman masa hidupnya setelah Rāsyid Riḍā tetapi pandangan-pandangannya setajam dengan pendapatnya.

\section{E. Penutup}


Pembahasan hadis prediktif dalam kitab Șaḥịh al-Bukhārī ini dapat disimpulkan sebagai berikut: pertama, Hadis prediksi sebuah hadis yang bukan bersumber dari Nabi tetapi merupakan sebuah hadis yang diformulasikan oleh generasi awal Islam yang diakuinya seolah-olah bersumber dari Nabi. Secara filosofis hadis prediksi bukan bersumber dari Nabi dibuktikan bahwa tugas Muhammad sejak awal diutus Allah SWT, di kota Makkah adalah bertujuan membebaskan praktek-praktek kāhin (peramal) yang menjurus pada penyekutuan terhadap Allah (syirik). Karena itu Muhammad di tegaskan oleh Allah bukan seorang yang gila (tukang sihir atau peramal) sebagaimana dituduhkan oleh orang-orang musyrik. Sebagaimana ditunjuk dalam al-Qur'an, 52: 29.

Kedua, dari sebagian contoh-contoh hadis prediksi yang diteliti dari kitab sahih al-Bukhari, terhadap unsur sanad dengan metode pen-takhrij-an sanad hadis, telah memberikan hasil bahwa hampir semua sanad hadis prediksi adalah bersetatus melaui periwayatan aḥad (tunggal). Hadis prediksi dengan periwayatan melalui jalur aḥad tidak bisa dipertahankan kredibelitasnya ketika hadis tersebut terjadi tadlis, waham dan gaira ittisāl (tidak bersambung).

Ketiga, matan hadis prediksi sebuah hadis yang seharusnya tidak di-marfu'-kan kepada Nabi, tetapi merupakan hadis mauquf yang disandarkan kepada sahabat, dan maqtu' yang disandarkan kepada tābi'īn ataupun itbā' tābi'īn. Kredibelitas matan hadis prediksi, tergantung pada keadaan kriteria sanad hadis. Kriteria terhidar dari 'illat (cacat) pada sanad hadis, adalah sangat menentukan terhadap keadaan kredibelitas matan hadis, tetapi keadaan kredibelitas pada sanad hadis tidak serta merta menjadi kredibelitas pada matan hadis. Sebagian Matan hadis prediktif dalam kitab sahih al-Bukhari mempunyai 'illat dalam sanad hadis dan'illat dalam matan hadis. Matan hadis-hadis prediksi yang diteliti baik secara langsung maupun tidak langsung adalah mengandung'illat karena bertentangan dengan al-Qur'an, mengandung hal-hal yang bersifat politis, serta mengandung pertentang teologis dan dogmatis.[]

\section{DAFTAR PUSTAKA}

Abdullah, Amin, Studi Agama: Normativitas dan Historisitas, Yogyakarta: Pustaka Pelajar, 1996. 
Dep. Pendidikan dan Kebudayaan, Kamus Umum Bahasa Indonesia, Jakarta: Balai Pustaka, 1988.

Elias, Elias A, Qamūs Elyas al-'Așriy, Mesir: Dār Gharīb li al-Ṭabā'ah, 1976.

Ibn al-Ṣalālah, Abū 'Amr 'Uṡmān bin 'Abd al-Karīm, 'Ulūm al-Hadīś, al-Madīnah alMunawarah: Maktabah Al-Islamiyah, 1972.

Ibn Manzūr, Abī al-Faḍl Jamīl al-Dīn Muhạmmad bin Mukrim, Lisān al-'Arab, juz II, Birūt: Dār Șadir, tth.

Ma'lūf, Louis, al-Munjid al-Abjadī, Beirūt: Dār Al-Masyāriq, 1967.

Muhibbin, Telaah Ulang atas Kriteria Kesahihan Hadis-Hadis al-Jāmi' al-Ṣaḥịh, disertasi, Yogyakarta: IAIN Sunan Kalijaga, 2003.

Muzī, Yūsuf bin al-Zakī Abd al-Raḥmān Abū al-Ḥajjāj, Tahżīb al-Kamāl, Juz VI, Beirūt: Muassasah al-Risālah, 1980.

Partanto, Pius A., dkk., Kamus Ilmiah, Surabaya: Arkola, 1994.

Rāzī, Muḥammad bin Abū Bakr bin Abd al-Qādir, Mukhtār al-Ṣāḥaḥ, Juz II, Bairut: T\{aba'ah Jadīdah, 1952.

Rahman, Fazlur, Islam and Modernity: Tranformation of an Intellectual Tradition, Chicago, University of Chikago Press, 1985.

Rahman, Fazlur, Islam, Chicago: University of Chikago Press, 1979.

Rahman, Fazlur, Islamic Methodology In History, Karaci: Central Institute of Islamic Reserch, 1965.

Riḍā, Muhammad Rāsyid, Tafsir Al-Manār, juz VIII, Beirūt: Dār al-Ma'rifah, tth.

Șāliḥ, Subki 'Ulūm al-Hadìs wa Musțalāhuhu, Beirūt: Dār al-'Ilmi, 1978.

Syāfi'i, Abī Abd Allāh Muhammad bin Idrīs, Ikhtilāf al-Hadīs, Beirūt: Dār al-Kutub al'Ilmiyah, 1986.

Żahabī, Syams al-Dīn Abū 'Abd Allāh Muhammad bin Muhammad, Sair A'lām alNubala', Juz XVIII, tp: Mu'asasah al-Risālah, 1985.

\section{Catatan Akhir}

${ }^{1}$ Amin Abdullah, Studi Agama: Normativitas dan Historisitas, Yogyakarta: Pustaka Pelajar, 1996, h. 308-309.

2Fazlur Rahman, Islamic Methodology in History, Karaci: Central Institute of Islamic Reserch, 1965, h. 33.

3Fazlur Rahman, Islam and Modernity: Tranformation of an Intellectual Tradition, Chicago, University of Chicago Press, 1985, h. 80.

4Muhammad bin Abū Bakr bin Abd al-Qādir al-Rāzī, Mukhtār al-Ṣạhah, Juz II, Bairut: Taba'ah Jadīdah, 1952, h. 27-30.

${ }^{5} \mathrm{Abī}$ Abd Allāh Muhammad bin Idrīs al-Syāfi'ì, Ikhtilāf al-Hadīs, Beirūt: Dār al-Kutub al'Ilmiyah, 1986, h. 369.

${ }^{6}$ Muhibbin, Telaah Ulang atas Kriteria Kesahihan Hadis-Hadis al-Jāmi' al-Ṣaḥịh, Disertasi, Yogyakarta: IAIN Sunan Kalijaga, 2003, h. 106.

7 Fazlur Rahman, Islam and Modernity, h. 9-14.

8 al-Rāzī, Mukhtār al-Sāhahah, I, h. 167.

${ }_{9}$ Abī al-Faḍl Jamīl al-Dīn Muḥammad bin Mukrim Ibnu Manzūu, Lisān al-'Arab, juz II, Birūt: Dār Șadir, tth, h. 131. 
10 Subki Șālih, 'Ulūm al-Hadīs wa Musțalāhuhu, Beirūt: Dār al-'Ilmi, 1978, h. 3.

${ }^{11}$ Fazlur Rahman Islam, Chicago: University of Chicago Press, 1979, h. 68-69.

12Ibid., h. 116.

13 Pius A. Partanto, dkk., Kamus Ilmiah, Surabaya, Arkola, 1994, h. 619.

${ }^{14}$ Elias A Elias, Qamūs Elyas al-'Așriy, Mesir: Dār Gharīb li al-T\{abā'ah, 1976, h. 563.

15Dep. Pendidikan dan Kebudayaan, Kamus Umum Bahasa Indonesia, Jakarta: Balai Pustaka, 1988, h. 924.

16 Fazlur Rahman, Islamic Methodology, h. 46.

17Huruf w $(\sin )$ dalam bahasa Arab merupakan huruf yang ke dua belas dari huruf hijaiyah dan huruf ini selalu diikuti bersama dengan kata kerja (fíil muḍāri) yang menunjukkan waktu akan datang tak terbatas (Louis Ma'lūf, al-Munjid al-Abjadī, Beirūt: Dār Al-Masyāriq, 1967, h. 528, 571).

18Yūsuf bin al-Zakī Abd al-Rahmān Abū al-Hajjāj al-Muzī,Tahżīb al-Kamāl, Juz VI, Beirūt: Muassasah al-Risālah, 1980, h. 518.

${ }^{19}$ Ibn 'Abd al-Bar adalah Abū ‘Umar Yūsuf bin 'Abd al-Bar al-Namarī (368 - 463 H) (lih. Syams al-Dīn Abū 'Abd Allāh Muḥammad bin Muḥammad al-Z|ahabī,Sair A'ām al-Nubala', Juz XVIII, h. 153).

${ }^{20}$ Fazlur Rahman, Islamic Methodology, h. 57.

${ }^{21} \mathrm{Abū}$ 'Amr 'Uṡmān bin 'Abd al-Karīm Ibn al-Ṣalālah, 'Ulūm al-Hadīs, al-Madīnah alMunawarah: Maktabah Al-Islamiyah, 1972, h. 197.

${ }^{22}$ Fazlur Rahman, Islamic Methodology, h. 55.

23 al-Żahabī, Sair A'lām al-Nubala', Juz VI, h. 141.

${ }^{24}$ Muhammad Rāsyid Riḍā, Tafsir Al-Manār, juz VIII, Beirūt: Dār al-Ma'rifah, tth, h. 185187. 